\title{
RHETORICAL CONSTRUCTION OF WEST AFRICAIN TRAVELS IN WEST AFRICA
}

\author{
Shuv Raj Rana Bhat*
}

\begin{abstract}
Viewed from David Spurr's lenses developed in "The Rhetoric of Empire," Mary Kingsley produces knowledge of West Africa and establishes a claim over her in her travelogue Travels in West Africa. Through the deployment of surveillance, appropriation, debasement and negation, she draws an ambivalent picture of Africa: one associated with filth, defilement, danger, darkness and death and the other endowed with natural vegetation and resources. Both sides of the picture call for the arrival of the British to improve the lifestyle of the Africans and to utilize the natural resources.
\end{abstract}

Key Words: Surveillance, appropriation, debasement and negation.

In this research, I accept David Spurr's invitation in The Rhetoric of Empire: Colonial Discourse in Journalism, Travel Writing, and Imperial Administration to employ his critical reading strategies to investigate European, particularly British ethnographic discourses of African cultures. Published by the Duke University Press in 1993, The Rhetoric of Empire is David Spurr's richly eclectic and innovative work in the postcolonial studies. Designed as "a general introduction to modern European colonial discourse" (1), the book identifies and explores "a series of basic tropes which emerge from the Western colonial experience" (3). The series of tropes of colonial discourse entails surveillance, appropriation, aestheticization, classification, debasement, negation, affirmation, idealization, insubstantialization, naturalization, and eroticization. These rhetorical conventions are epistemological lenses through which the West produces the knowledge of, and subsequently establishes a claim over the non-West. Such symbolic dominance served the colonial enterprise in the past and it is still far from being extinct today. According to Spurr, these eleven modes constitute "a kind of repertoire for colonial discourse, a range of tropes, conceptual categories, and logical operations available for purpose of [colonial] representation" (3).

* Mr. Rana Bhat is Lecturer in English at Central Department of English, T.U., Kirtipur, Nepal 
Similar to Mary Louise Pratt, David Spurr recognizes colonial discourse in his reading of Western travel, journalistic and administrative writings about other non-Western cultures both in the modern period of European colonialism and in the more recent period of decolonization. Drawing examples from nineteenth and twentieth century British, French and American writings, he emphasizes on rhetorical analysis rather than historical narrative. The examples show how the western writers rely heavily on signifiers such as dirt, disorder, disease, unfavourable climate, grave, and dire poverty to convey the message.

Spurr discusses rhetoric "as being not just the study of tropes and figures, but also a procedure that suspends the internal logic of a given trope in order to place it within a larger narrative framework which includes the history of literature and of philosophical thinking" (8). Here, rhetoric is connected to the human thoughts and basic assumptions the speakers and listeners live by, perhaps without questioning how their persuasive functions have guided human action. According to Spurr, rhetoric has its pattern of persuasion. The rhetorical strategy is usually repetitive, and therefore can be carefully deconstructed. Consequently, rhetorical strategy can be understood as the science or art of using language in a careful yet predictable way in order to accomplish certain goals that determine social action.

The first relevant rhetorical convention with which begins David Spurr's The Rhetoric of Empire is surveillance, or visual observation of the Oriental landscape and bodies. The word "surveillance" indicates looking which according to Spurr "is never innocent or pure, never free of mediation by motives which may be judged noble or otherwise" (27). Spurr further contends that "The writer's eye is always in some sense colonizing the landscape, mastering and portioning, fixing zones and poles, arranging and deepening the scene as the object of desire" (27). Bearing a strong connection to Foucault's panoptic on, a metaphor of the encompassing eye of power, surveillance of landscape paintings, architecture, sites of tourism, scientific research and hypnotizing places offers the onlooker aesthetic pleasure on the one hand, knowledge and authority on the other. For the observer, the "sight confers power; for the observed, visibility is a trap" (16). The examination of the sweeping Oriental landscape and the staring-down of Oriental people by Western travelers reveal the colonial desire to establish knowledge of and authority over the cultural Other. 
Spurr discusses the rhetoric of surveillance with regard to landscapes, interiors and bodies. "Monarch-of-all-I-survey" is what Mary Louise Pratt calls this rhetorical gesture based on the sweeping visual mastery of a scene, an important feature of the nineteenth century travel narratives. On the $20^{\text {th }}$ of September 1895, Mary Kingsley surveys the scene with aesthetic valorization of the landscape:

This road is quite the most magnificent of roads, as regards breadth and general intention, that I have seen anywhere in West Africa, and it runs through a superbly beautiful country. It is, I should say, as broad as Oxford Street; on either side of it are deep drains to carry off the surface waters, with banks of varied beautiful tropical shrubs and ferns, behind which rise, 100 to 200 feet high, walls of grand forest, the column-like tree-stems either hung with flowering, climbing plants and ferns, or showing soft red and soft grey shafts sixty to seventy feet high without an interrupting branch. Behind this again rise the lovely foot hills of Mungo, high up against the sky, coloured the most perfect soft dark blue. (199)

In the extract above, Kingsley uses nouns qualified by adjectives mostly in the positive and superlative forms and followed by modifiers in the forms of gerund to express her aesthetic pleasure. To describe the road in West Africa, she deploys adjectives such as "the most magnificent," and "banks of varied beautiful tropical shrubs and ferns." She equates this African road with the road in England in terms of its breadth, "as broad as Oxford Street." Her description of the landscapes moves with the mathematician's eye suggested by " 100 to 200 feet high walls of grand forest ... showing soft red and soft grey shafts sixty to seventy feet high without an interrupting branch." The last phrase "the most perfect soft dark blue" invests the scene of foothills of Mungo with aesthetic value or power.

Part of the sentence "I hope I may be pardoned for entering into this subject," the subject of the trade of the West African Coast inaugurates Kingsley's twenty first chapter entitled "Trade and Labour in West Africa." Linguistically speaking, the word "pardon" in this context presupposes that the user has done something disallowed to her and therefore is asking for excuses or forgiving. Kingsley's expression posits that her visit to West Africa is invested with economic interest. She makes it clear when she says:

Africa does not possess ready-made riches to the extent it is in many quarters regarded as possessing. It is not an India filled with the accumulated riches of ages, waiting for the adventurer to enter and shake the pagoda tree. The pagoda tree in Africa only grows over stores of buried ivory, and even then it is a stunted specimen to that 
which grew over the treasure-houses of Delhi, Seringapatam, and hundreds of others as rich as they in gems and gold. Africa has lots of stuff in it; structurally more than any other continent in the world, but it is very much in the structure, and it requires hard work to get it out, particularly out of one of its richest regions, the West Coast, where the gold, silver, copper, lead, and petroleum lie protected against the miner by African fever in its deadliest form, and the produce prepared by the natives for the trader is equally fever-guarded, and requires white men of a particular type to work and export it successfully - men endowed with great luck, pluck, patience, and tact. (227)

Kinsley's expression "waiting for the adventurer to enter and shake the pagoda tree" hints at the fact that travel writers during the nineteenth century made their frequent visits to Africa and India to amass the riches available there. The way she surveys the West Coast postulates that it has economic value, with gold, silver, copper, lead, and petroleum lying protected against the miner by African fever in its 'deadliest form.' In this particular scene, Kingsley creates two-facetimage of Africa--one in the positive--replete with rich minerals and the other in the negative- infested with disease. She necessitates a situation in which white intervention is indispensable, only white men with great luck, pluck, patience and tact is capable of extracting and exporting the riches from the deadliest place called Africa.

The second visual terrain through which the European traveler's eye travels is the interior of the non west. Mary Louise Pratt elaborates on this issue of interior under the rubric of planetary consciousness. Having descended from the pinnacle of the mountains, the surveillance of the European traveler penetrates the inner parts of human habitation, exploring the bodies of the travelee minutely. Referring to how the policing eye of the Western travel writer surveys the world other than the West, David Spurr observes, "The eye of the writer and its technological extension, the camera, take us inside the dwelling places of the primitive and exotic: a night club in Saigon, sacred caves in India, a terrorist enclave in Beirut, the winding alleys of the Algerian casbah, a prison in Uganda, a peasant hut in El Salvador" (19). It is in these interior spaces of non-European peoples that the confrontation of cultures takes place face to face.

Kingsley transports the readers to the street of Free Town in Sierra Leone, where she surveys with her imperial eyes the lifestyle of a man, particularly the way he dresses, "The ordinary man in the street wears anything he may have been able to acquire, anyhow, and he does not fasten it on securely" (9). Whereas Kingsley does not take us inside 
the night clubs, she does take us inside the interior part of Africa, where she shows the possibility of confrontation between the colonizer and the colonized. She writes: "If the white trader goes into the interior, he has to face, first, the difficulty of getting his goods there safely; secondly, the opposition of the native trader who can, and will drive him out of the market, unless he is backed by easy and cheap means of transport" (230). Just a few paragraphs following this description, Kingsley equates her native country England with European rivals France and Germany in terms of audacity and endeavour required for the penetration of the inland of Africa: "The Niger Company has broken through, and taken full possession of a great interior, doing a bit of work of which every Englishman should feel proud, for it is the only thing in West Africa that places us on a level with the French and Germans in courage and enterprise in penetrating the interior" (213).

Human body is the last field that is surveyed by the traveler. According to Spurr, "the body of the primitive becomes as much the object of examination, commentary, and valorization as the landscape of the primitive" (22). Spurr further adds, "Under Western eyes, the body is that which is most proper to the primitive, the sign by which the primitive is represented. The body, rather than speech, law, or history, is the essential defining characteristic of primitive peoples" (22). In colonial discourse, the body is said to have various kinds of values such as aesthetic value of body as object of artistic representation, the material value of body as labour supply, the ethical value of body as a mark of innocence or degradation, the humanitarian value of body as a sign of suffering and the erotic value of body as the object of desire. The imperial eyes treat the body as though it is a landscape, proceeding from part to part, noting colour and texture and finally passing an aesthetic judgment.

In the following description of the Igalwa women, Kingsley minutely observes different parts of women such as hands, feet, teeth and eyes although she is far more interested in recording her dealings with Fan chiefs and Kru-boys. She writes:

[The Igalwa ladies are] the comeliest ladies I have ever seen on the Coast. Very black they are, blacker than many of their neighbours, always blacker than the Fans, and although their skin lacks that velvety pile of the true negro, it is not too shiny, but it is fine and usually unblemished, and their figures are charmingly rounded, their hands 


\section{RHETORICAL CONSTRUCTION OF WEST...}

and feet small, almost as small as a high-class Calabar woman's, and their eyes large, lustrous, soft and brown, and their teeth as white as the sea surf and undisfigured by filing. (223)

Particularly interesting thing in this ethnographic description of African women is the authority Kingsley exhibits. Referring to this visual survey, Laura E. Ciolkowski in the article entitled "Travelers' Tales: Empire, Victorian Travel, and the Spectacle of English Womanhood in Mary Kingsley's Travels in West Africa" comments, "Kingsley's detailed catalogue of the relative merits and charms of African women is not simply an expression of an English woman's unsanctioned exercise of the gender-coded visual power from which she is traditionally excluded; it is, in fact, one of the generic requirements of Western ethnographic descriptions of foreign peoples" (343). Kingsley's orientalist assessment of African women unselfconsciously displays the racial privilege with which she is invested to describe her culture's "others." Using racionyms repeatedly "black," "blacker," "always blacker" and "negro," Kingsley projects her racist attitude towards the Afro-Americans.

The second rhetorical trope David Spurr introduces in The Rhetoric of Empireis that of appropriation which has to do with inheriting the earth. Introducing the trope of appropriation, Spurr maintains, "Colonial discourse takes over as it takes cover. It implicitly claims the territory surveyed as the colonizer's own; the colonizer speaks as an inheritor whose very vision is charged with racial ambition" (28). This possessive vision of the colonizer, nonetheless, simultaneously masks itself by transforming it into a response to an appeal made by the colonized. This appeal may manifest itself in at least three forms - chaos, absence and profusion of natural resources that respectively call for order, affirming presence and creative hand of technology from the west (28). In order to substantiate this contention, Spurr quotes the governor general of French Indochina during the early twentieth century, Albert Sarraut who shows an uneven distribution of nature's twin abundance of material and intellectual resources owing to which one is cut off from the other. He writes:

While in a narrow corner of the world nature has concentrated in white Europe the powers of invention, the means of progress, and the dynamic of scientific advancement, the greatest accumulation of natural wealth is locked up in territories occupied by backward races who, not knowing how to profit by it themselves, are even less capable of releasing it to the great circular current that nourishes the ever growing needs of humanity. (qtd. in Spurr 29) 
In the quote above, Sarraut clearly bestows positive qualities-powers of invention, scientific advancement and means of progress on the Europeans which are required to unlock the world's greatest natural wealth lying buried in the "territories occupied by the backward races."

In chapter twenty one, Kingsley presents the West Coast as the land endowed with "the gold, silver, copper, lead and petroleum" which are awaiting the arrival of "white men of a particular type to work and export [them] successfully-men endowed with luck. Pluck, patience and tact" (227). In the same chapter, Kingsley depicts the Ancobra, "a river which penetrates the interior, through a district very rich in gold and timber and ... petroleum," (229) waiting for the technology of the West for their extraction from the mines. Kingsley further shows how European countries such as Britain, France, Spain and Portugal are in competition with one another in order to conquer the land in Africa. She writes, "The regions of richest oil are not in our possessions, but in those of Germany, France, Spain, and Portugal, namely the Cameroons and its volcanic island series, Fernando Po, Principe, and San Thome" (233). The expression "the richest oil are not in our possessions" presupposes that Kingsley is employed by British Empire as an agent to expand the colony of Britain in Africa. She admits that English have always been "rapacious land grabbers ... and where after all is the harm in it?" (254).

European colonial travel writers see the natural resources of colonized lands as belonging rightfully to civilization and mankind rather than the indigenous people who inhabit those lands. Frederick Lugard, the British governor of general of Nigeria "considers the European powers to be "custodians of the tropics" and "trustees of civilization for the commerce of the world" (qtd. in Spurr 28). Under the guise of a humanitarian, Kingsley shows how France and Germany appropriate the rich African region:

I always admire a good move in a game or a brilliant bit of strategy, and that was a beauty; and on our head now lie the affairs of the Congo Free State, while France and Germany smile sweetly, knowing that these affairs will soon be such that they will be able to step in and divide that territory up between themselves without a stain on their character - in the interests of humanity - the whole of that rich region, which by the name of Livingstone, Speke, Grant, Burton, and Cameron, should now be ours. (354) 
France and Germany's ability to divide the land themselves "without a stain on their character" suggests that they are expert land grabbers who approach Africa in the guise of humanitarians, indicated by "in the interests of humanity." Extolling the strategy adopted by France and Germany, Kingsley makes the readers see British rapacious eyes on the Congo areas.

Under appropriation, I have so far pointed out two strategies by which the non-western world is made to invite invasion- "one that of nature, which calls for the wise use of its resources" and the other "that of humanity, which calls for universal betterment" (Spurr 34). Colonial intervention also responds to a third calling, "that of the colonized, who call for protection from their own ignorance and violence" (34). One possible way to gain knowledge is through learning the language of the colonizer. The white colonizer makes the colonized see him as "his ruling man, rich, powerful, and honoured" (151). The ruled begins to imitate him and "goes to the mission-school classes to read and write, and as soon as an African learns to read and write he turns into a clerk" (151).

In order to show grammatical forms of appropriation, David Spurr cites Roland Barthes who claims that nomination is "first procedure of distraction" (32). Building on the Barthes' idea of nomination, Spurr forms an argument: "Nomination and substantivisation may also be seen as grammatical forms of appropriation: by naming things, we take possession of them" (32). In chapter twenty one, Kingsley describes Kruboys' behaviors and activities in a greater detail. Kingsley is not happy with the name of a Kruboy, whose name is You-be-d-d. His name being improper, protracted and calling for change of some sort, she "christened him Smiles" (240). She chooses an English name for her western audience. In other words, she constructs an Africa, understandable to targeted audience.

Associated with filth and defilement, the rhetoric of debasement is concerned with the text's reproduction of myths about the non-west that creates an image of a foreign place that is somehow abhorrent or dangerous to Europeans. The common themes associated with debasement-"dishonesty, suspicion, superstition, lack of selfdiscipline - are reflected more generally in societies characterized by corruption xenophobia, tribalism, and the inability to govern themselves" (Spurr 76). Likewise, "social problems in health and sanitation, 
unemployment, or population growth come to be associated with individual filth, indolence, and sexual promiscuity" (77). The belligerence of Arab nations, for instance, is traced to the violence and fanaticism of the Arab character.

Similar to classification, the rhetoric of debasement basically helps to make a clear distinction between the colonizer and the colonized. Since it aims to illustrate the lowest qualities of the colonized, this rhetorical strategy justifies the western intervention or domination of other countries. The following expression by the French colonial administrator Albert Sarraut bespeaks why western intervention is mandatory:

Without us, without our intervention ... these indigenous populations would still be abandoned to misery and abjection; epidemics, massive endemic diseases, and famine would continue to decimate them; infant mortality would still wipe out half their offspring; petty kings and corrupt chiefs would still sacrifice them to vicious caprice; their mind would still be degraded by the practice of base superstition and barbarous custom; and they would perish from misery in the midst of unexpected wealth. (qtd. in Spurr 77)

Right in the introductory chapter, Mary Kingsley depicts Africa as a dangerous place to Europeans. She mentions that prior to visiting Africa she endeavored to collect as much information about Africa as possible through her friends, but majority of them were unknown to it. The only information she collected involved, "Oh, you can't possibly go there; that's where Sierra Leone is, the white mans grave, you know," "deadliest spot on earth" and "I wouldn't go there if I were you" (1). These warnings given by Kingsley's friends reduce African land to a graveyard that generates terror in the readers. Similarly, in chapter three entitled "Voyage Down Coast" Kingsley speaks of horrifying danger in the West Coast of Africa:

The more you know of the West Coast of Africa, the more you realize its dangers. For example, on your first voyage out you hardly believe the stories of fever told by the old Coasters. That is because you do not then understand the type of man who is telling them, a man who goes to his death with a joke in his teeth. But a short experience of your own, particularly if you happen on a place having one of its periodic epidemics, soon demonstrates that the underlying horror of the thing is there, a rotting corpse .

In this extract, Kingsley equates Africa with a cemetery through the horrendous image of "a rotting corpse." Africa is debased through the signifiers such as danger, mystery, disease and death. 


\section{RHETORICAL CONSTRUCTION OF WEST...}

In chapter one while travelling from Liverpool to Sierra Leone and the Gold Coast, Kingsley constructs a negative image of The Gold Coast. Referring to the Gold Coast, says Kingsley, "seen from the sea it is a pleasant looking land. The long lines of yellow, sandy beach backed by an almost continuous line of blue hills, which in some places come close to the beach, in other places show in the dim distance. It is hard to think that it is so unhealthy as it is, from just seeing it as you pass by" (14). From a distance, Gold Coast is so hypnotizing that imperial eyes cannot resist the temptation. But the "unhealthy" Africa betrays them, transforming their temptation into frustration. However, Kingsley does not associate this problem with African's filth, indolence and sexual promiscuity as done by Spurr in The Rhetoric of Empire.

Travels in West Africa is constituted by twenty two chapters spreading over two hundred and sixty six pages. Among them, the last chapter is entitled as "Disease in West Africa" in which she very clearly gives two reasons why Africa remains undeveloped despite having immense natural resources - one because of the labour problem and the other owing to "the deadliness of the climate" (258). She writes, "Other parts of the world have more sensational outbreaks of death from epidemics of yellow fever and cholera, but there is no other region in the world that can match West Africa for the steady kill, kill, kill that its malaria works on the white men who come under its influence" (259). Kingsley reiterates what one of her friends before she visited Africa said of West Africa, "the deadliest spot on earth."

In the same way, the West Africans are portrayed as being highly superstitious. Kingsley in the chapter eight entitled "Fetish" provides a detailed description of the superstitious activities practiced by local people. "One thing about Negro and Bantu races," writes Kingsley, "is very certain, and that is that their lives are dominated by a profound belief in witchcraft and its effects" (154). The Calabar peoples are said to believe in the existence of four souls in human being: the soul that survives death, the shadow on the path, the dream-soul and the bush-soul. When a person falls sick, it is because his bush-soul is furious at being neglected and a witchdoctor is immediately called in to attend to the sufferer. The witchdoctor diagnoses this disease as being the cause of complaint and prescribes certain offerings to the offended one. If the offering does not work well on the bush-soul, the patient dies. Another peculiarity about the bush-soul is related to the old people who are highly 
esteemed among the Calabar tribes. Their longevity is connected to their possession of powerful bush-souls.

The Niger Delta tribes are represented as having a strong belief in the idea of reincarnation. Explaining why a person dies, Kingsley speaks, "he may have had a bad illness from some cause in his previous life and, when reincarnated, part of this disease may get reincarnated with him and then he will ultimately die of it. There is no medicine of any avail against these reincarnated diseases" (155). She further states that the belief in witchcraft is the major cause of more African deaths than anything else. The backwardness of Africans is ascribed to their strong belief to superstition. Kingsley confidently declares that the African "will never advance [their culture] in the line of European culture. The country he lives in is unfitted for it, and the nature of the man himself is all against it - the truth is the West Coast mind has got a great deal too much superstition about it, and too little of anything else" (257). Kingsley's assertion of the Africans calls for the western intervention for educating them or elevating them to the level of the Europeans.

"Areas of darkness" is the phrase Spurr uses to qualify the rhetoric of negation by which the Other is conceived as absence, emptiness and nothingness by the Western writers. He argues that this rhetorical trope leads to the formation of two principles: "first, negation serves to reject the ambiguous object for which language and experience provide no adequate framework of interpretation; second. . . negation acts as a kind of provisional erasure, clearing space for the expansion of the colonial imagination and for the pursuit of desire" (92-93).

Spurr basically discusses the rhetoric of negation in terms of space, history and language of the colonized peoples. Indigenous people are presented as inhabiting a temporal space; their culture is timeless and without history and their language is reduced to a babble. Mary Louise Pratt calls this phenomenon "deterritorialization," the process of removing time, history and context from a culture and reducing it to an inventory of attributes. Unlike Europeans, the local people of Africa become trapped in a timelessness that is seen as intrinsic to their culture and way of life. To show how negation operates, Spurr cites Charles Darwin, who in the conclusion to his Journal issued in 1839, records the most impressive scene from the vast and empty lands of Patagonia:

They are characterized only by negative possessions; without habitations, without water, without trees, without mountains. ... Why then, and the case is not peculiar to myself, have these arid wastes 


\section{RHETORICAL CONSTRUCTION OF WEST...}

taken so firm possession of the memory? . . . I can scarcely analyze these feelings: but it must be partly owing to the free scope given to the imagination. (91)

Though descriptive outwardly, Darwin's imagery of nothingness in Patagonia actually serves his official purpose, the colonization of the natural world by scientific knowledge. Kingsley disperses negative spaces throughout her narrative. One such scene from Travels in West Africa is about the West Coast of Africa which, to her, is analogous to the North Pole, a place lacking human habitation:

The West Coast of Africa is like the Arctic regions in one particular,
and that is that when you have once visited it you want to go back
there again; and, now I come to think of it, there is another particular
in which it is like them, and that is that the chances you have of
returning from it at all are small, for it is a Belle Dame sans merci.(6)

Comparing West Coast of Africa with the Arctic regions, Kingsley provides an ambiguous picture of Africa - a place devoid of all facilities required for the human habitation on the one hand, and also a place having a tantalizing or hypnotic effect on the other. Moreover, she ascribes feminine quality to Africa, indicated by the metaphor of "a Belle Dame sans merci," a woman beautiful enough to arrest the lusty and rapacious eyes of the colonizers and at the same time a merciless being capable of destruction like death.

While describing the great regions of mangrove-swamps, Kingsley follows what Richard Harding Davis teaches, "To tell what the place is like, you must tell what it lacks" (qtd. in Spurr 96). Having invested much of the spaces on the negative construction of the natives, Kingsley finally renders the land as devoid of eating things, "And the region is practically foodless" (37).

The rhetoric of negation implies that the indigenous people have neither history nor place, constituting the past as absence. Nor do they speak the language of the civilized humanity. One of the many Europeans Spurr cites in his book to discuss the absence of history is Hegel, who finds Africa unhistorical: "What we properly understand by Africa, is the Unhistorical, Undeveloped Spirit, still involved in the conditions of mere nature" (98). By denying history to the Africans, Hegel seems to suggest that it belongs only to Europe. Whereas Kingsley does not directly deal with history of the local people in Africa, she does bring this into discussion through the concept of time, which is inclusive of past, present and future. According to her, 
"Divisions of time the Bubi can hardly be said to have, but this is a point upon which all West Africans are rather weak, particularly the Bantu "(28). Here the dichotomy of presence and absence is clearly seen. Kingsley removes the time, history and context from the culture of the Bubi and the Bantu peoples as opposed to her own, characterized by the presence of time evidenced in the very diary-like memoir.

As Spurr's lenses testify, Kingsley produces the knowledge of West Africa and establishes a claim over her. Through the deployment of surveillance, appropriation, debasement and negation, she draws an ambivalent picture of Africa: one associated with filth, defilement, danger, darkness and death and the other endowed with natural vegetation and resources. Both sides of the picture call for the arrival of the British to improve the lifestyle of the Africans and to utilize the natural resources.

\section{WORKS CITED}

Birkett, Dea (1992). Mary Kingsley: Imperial Adventures. London: Macmillan.

Brisson, Ulrike (2005). "Fish and Fetish: Mary Kingsley's Studies of Fetish in West Africa." Journal of Narrative Theory. 35.3: 32640 .

Ciolkowski, Laura E. (1998). “Travelers' Tales: Empire, Victorian Travel, and the Spectacle of English Womanhood in Mary Kingsley's Travels in West Africa." Victorian Literature and Culture. 26.2: 337-66.

Crowley, Sharon and Debra Hawhee (2004). Ancient Rhetorics for Contemporary Students. $3^{\text {rd }}$ ed. New York: Pearson Education.

Hackett, Rosalind I.J. (1991). "Review of Travels in West Africa."Journal of Religion in Africa. 21.1: 78-82.

Kingsley, Mary H. (1897). Travels in West Africa. London: Macmillan.

Mills, Sara (1991). Discourses of Difference: An Analysis of Women's Travel Writing and Colonialism. London: Routledge.

Morlin, Karen (1995). "Travel, Gender, and Imperialism: Mary Kingsley and West Africa." Annalsof the Association of American Geographers. 85.4: 753-55.

Pratt, Mary Louise (1992). Imperial Eyes: Travel Writing and Transculturation. $2^{\text {nd }}$ ed. London: Routledge. 
Spurr, David (1993). The Rhetoric of Empire: Colonial Discourse in Journalism, Travel Writing, and Imperial Administration. Durham: Duke University Press.

Taylor and Francis (1897). Folklore. 8.2: 162-65.

Tobin, Jennifer (2000). Discourse and Psyche: Three Women's Texts of Empire. Diss. University of Illinois, 2000. Ann Arbor: UMI, 9990166.

Vye, Shelly (2004). Tourist Geographies: Spectatorship, Space, and Empire in England, 1830-1990. Diss. Syracuse University, 2004. Ann Arbor: UMI, 3132718. 